Article

\title{
Teacher Training in Intercultural Education: Teacher Perceptions
}

\author{
Victoria Figueredo-Canosa ${ }^{1, *}$, Luis Ortiz Jiménez ${ }^{1} \mathbb{D}$, Cristina Sánchez Romero $^{2}$ and \\ María Carmen López Berlanga 3 \\ 1 Department of Education, Faculty of Education Sciences, University of Almeria, 04120 Almeria, Spain; \\ lortizj@ual.es \\ 2 Department of Didactic, Scholar Organization and Special Didactics, Faculty of Education, \\ National University of Distance Education, 28040 Madrid, Spain; csanchez@edu.uned.es \\ 3 López Vicuña School, 28037 Madrid, Spain; maricarmen@lopezvicu.es \\ * Correspondence: vfc310@ual.es
}

Received: 4 March 2020; Accepted: 19 March 2020; Published: 20 March 2020

\begin{abstract}
Background: The aim of the present study was to evaluate teacher perceptions on the training received in intercultural education. Methods: The article presents a quantitative, non- experimental and ex-post-facto type of research; directed to inquire about the perceptions of the teachers of primary education in Andalusia (Spain) in relation to the intercultural training received. Based on the descriptive survey method, two questionnaires were administered to a sample composed of 320 students and 80 teachers. Results: The results show certain strengths of the training teacher programs in the field of interculturality (encouragement of reflection, participation and collaboration ...), as well as weaknesses (decontextualization, inflexibility, primacy of theoretical learning, non-transversal character, etc.). Conclusions: Despite strengths, intercultural teacher training continues to be a challenge in Andalusia.
\end{abstract}

Keywords: teacher training; primary education; intercultural training

\section{Introduction}

The educational response to growing disturbing manifestations in society, such as racism or conflicts of coexistence between people of different cultures, stands as one of the priorities to face in the current Spanish educational system [1]. The intercultural education model provides a holistic view of the inclusion process of immigrant students. It is based on mutual respect, exchange, cooperation and peaceful coexistence among people from different cultures. In view of this, the teacher training offer related to attention to diversity has increased in recent years.

In the case of initial teacher training, it is possible to differentiate between three modalities through which attention to cultural diversity is included [2]:

(a) Transversal integration in the curriculum: Intercultural competences are developed transversally through the various subjects of the curriculum. This modality requires that the disciplinary foundations of each subject be articulated with those of interculturality. However, in practice it is observed that intercultural competences are not promoted from all the modules and subjects, but only from some considered related, such as: "Society, School and Democracy"; "Teaching social sciences"; "Language learning", etc. Teacher training for cultural diversity cannot respond to particular commitments of certain areas or departments but must be articulated in a coordinated manner by the set of responsible trainers. It is a process that must enjoy interdisciplinary support, from which the different specific didactics, together with the rest of the fields of knowledge, 
reinforce their commitment to the inclusion of cultural diversity as a key element in the process of learning to teach [3].

(b) Specific integration in the curriculum: Specific subjects in the field of attention to cultural diversity, both mandatory and optional, are incorporated into the curriculum. Despite being the most common modality in Spanish universities, this practice contradicts the foundations of the intercultural education model in the sense that specific subjects are incorporated to deal with a specific "problem".

(c) Project-based curricular integration: Participation in collaborative projects with the community that favor the acquisition of intercultural competences is included in the curriculum. A fundamental example of this type of modality is the methodology of apprenticeship service, considered one of the main learning pathways favoring the acquisition of intercultural competences [4].

On the other hand, in the case of in-service teacher training, there are four types:

(a) Training courses: Actions aimed at updating teaching competencies (scientific, technical, didactic, and professional) through contributions from specialists. Despite offering opportunities to update knowledge, to be carried out outside schools and at the individual level, sometimes can end up being decontextualized, away from the interests and real concerns of teachers, without a clear practical application, etc. The evaluations of this training modality show that they do not have a significant impact on school practices [5]. Considering that the intercultural approach implies exchange, cooperation and transformation of the school, it is difficult for individual courses carried out individually outside of practice to contribute to profound changes in the structure and function of the school system [6].

(b) Seminars and Congresses: Actions aimed at deepening the study of specific issues. These modalities favor the creation of meeting spaces that allow the updating of knowledge and exchanges with other professionals and experts in the intercultural field.

(c) Working groups: Actions directed to the elaboration of didactic materials and/or documents of reflection on interculturality, favoring the exchange of knowledge between professionals.

(d) Training in centers: Actions aimed at responding to the specific training needs of each teaching team. It is a training aimed at a center as a unit, favoring the planning and development of training activities adapted to each context. The training in the center itself and with a research-action dynamic is ideal for advocacy in intercultural practice, since it is carried out in the context in question and has implication for the school community directly [7]. This modality requires that teachers work collaboratively in the detection, analysis and prioritization of needs of the school itself, as well as in the proposal and development of initiatives that respond to these needs. For this, it is essential to create spaces open to debate in which the entire educational community and support networks that favor the support of the immediate environment participate. An example of training in centers is the PIFDEI Model (Integral Training and Dynamization Plan for the Intercultural and Inclusive School) [8], aimed at providing tools, procedures and instruments to transform educational centers in genuinely intercultural and inclusive contexts. This model is structured in three phases: awareness, planning and projection. It also includes training materials for each of them (readings, role playing, cooperation exercises, self-knowledge questionnaires, etc.).

Given the diversity of training methods, we consider it necessary to reflect on what characteristics should be presented by initial and in-service teacher training programs to promote the acquisition of intercultural skills and professional practice away from compensatory educational programs $[9,10]$, and segregation measures in schools [11]. Following different experts [12-17], the teacher training must conform to the following characteristics:

(a) Contextualized and flexible: Offer adequate responses to real and changing situations that derive from school and social contexts. Bearing in mind that there are no valid application formulas 
for any context, every training process must start from the needs and interests of the students, and be flexible to include the adaptations and changes that are necessary.

(b) Theoretical-practical: Favor the development of the necessary competences for the professional exercise relating theoretical learning with practice.

(c) Reflective: Provoke critical reflection on the elements that have an influence on school practice and in the formative processes of permanent form.

(d) Collaborative and participatory: Favor the work with the different agents that make up the educational community, as well as include active participation in cooperative experiences. Teachers are trained in interculturality when they coexist with teachers from other cultures [18] and participate in international educational networks, favoring their own personal and professional development, cultural awareness, teaching methodologies, and the choice of curricular content $[19,20]$. Along these lines the formative proposals directed to the international mobility of the teaching staff have proliferated.

(e) Of intercultural transversality: Promote the acquisition of intercultural competences from all the training disciplines.

(f) Dialogical: Facilitate the establishment of exchanges and debates in relation to the identification and treatment of problems, as well as in the search for solutions.

(g) Community: Directed to the entire educational community. It will only be possible to achieve intercultural schools if one has the participation and support of all social and educational agents.

In relation to the defined characteristics, different studies indicate that both initial and in-service teacher training does not conform to them. On the one hand, and in relation to initial teacher training, one study revealed that the design of the study plan of the Degree in Primary Education of the University of Castilla La Mancha does not explicitly contemplate the intercultural competence that future teachers have to develop at the end of their initial professional training [21]. Likewise, another study indicates that it can be deduced that intercultural teacher training presents an eminently optional character in the curricula of the Degree in Primary Education of the Public University of Navarra [22]. As a result, only teachers with interests in doing so participate in it. On the other hand, and in relation to in-service teacher training, the courses are designed and developed in a decontextualized way, and not as part of the needs and interests of the teachers themselves, and usually takes place outside the school context and working hours [23]. However, the courses can be an occasion for teachers to discuss and reflect about different pedagogical approaches, teaching strategies and practices in intercultural education [24]. Another study revealed that intercultural teacher training is not presented transversally in the Autonomous Community of Galicia, and therefore does not reach all the teaching staff, but rather is aimed especially at the teaching staff in direct contact with students of foreign origin and/or who belong to cultural minorities [25]. Finally, [26] indicated that the vast majority of secondary school teachers in Cádiz and Murcia state that they almost never engage in intercultural work outside the school. At this point, it is evident that in the initial and in-service teacher training there are gaps in relation to the attention to the cultural diversity of the students [27-30].

The present study aims at investigating and studying the perceptions of primary education teachers in Andalusia in relation to the training received in intercultural matters. In this line of thought, we set ourselves the following specific objectives:

- Know the perceptions and attitudes of the students in relation to the intercultural training offered by the Degree in Primary Education.

- Know the perceptions and attitudes of the teaching staff in relation to the intercultural training offered from the actions of permanent formation.

- Identify the characteristics present in the training programs that favor the intercultural training of the teaching staff.

- Detect the main shortcomings of the training programs in the field of intercultural teacher training. 


\section{Materials and Methods}

To respond to the proposed objectives, we chose to work from a fundamentally quantitative, non-experimental and ex-post-facto approach, with the purpose of trying to describe and explain the phenomenon to be investigated. More concretely, we worked from the approach of the descriptive survey method.

The population covered by this research included the students of the Primary Education Degree of the Public Universities of the Autonomous Community of Andalusia and in-service teachers of the Andalusian Educational System at the stage of primary education.

For the selection of the sample, an intentional opinion sampling was developed. This type of sampling allowed the participants of the sample to be selected intentionally, following strategic criteria (Tables 1 and 2) through which the most suitable and representative subjects of the population to be studied were selected [31].

Table 1. Strategic criteria for the selection of the research sample.

\begin{tabular}{cc}
\hline & Study $\mathbf{1}$ \\
\hline Subjects & Selection criteria \\
\hline Pre-service teachers & Institution (Public universities) \\
& Titling (Degree in Primary Education) \\
Course (Last year)
\end{tabular}

Table 2. Strategic criteria for the selection of the research sample.

\begin{tabular}{cc}
\hline Study $\mathbf{2}$ \\
\hline Subjects & Selection Criteria \\
\hline \multirow{3}{*}{ In-service teachers } & Education stage (Primary education) \\
& Experience (5 years) \\
& $\begin{array}{c}\text { Incidence of students of foreign origin in the center (Percentage greater than } 20 \%) \\
\text { Position (Tutor, support, therapeutic pedagogy and ATAL) }\end{array}$ \\
\hline
\end{tabular}

Finally, the sample was formed as follows (Table 3):

(a) 320 students in the last year of their Degree of Primary Education in the eight Public Universities of Andalusia. Specifically, 174 women and 146 men aged between 20 and 36 years $(M=22.68$, $\mathrm{SD}=2.58)$.

(b) 80 teachers from 16 Primary Education Centers (public and arranged) from different Andalusian provinces (Almería, Granada, Jaén, Málaga and Seville). Specifically, 44 women and 36 men between the ages of 32 and $55(\mathrm{M}=45.93, \mathrm{SD}=7.33)$.

Table 3. Distribution of the sample by type of participant, university, and province of work.

\begin{tabular}{cccc}
\hline \multicolumn{2}{c}{ Primary Grade Students } & Teachers in Active Primary Education \\
\hline College & No. & Province & No. \\
\hline Almeria & 40 & Almeria & 20 \\
Cadiz & 40 & Granada & 20 \\
Cordoba & 40 & Jaen & 20 \\
Granada & 40 & Malaga & 20 \\
Huelva & 40 & Seville & 20 \\
Jaen & 40 & TOTAL & 80 \\
Malaga & 40 & & \\
Seville & 40 & & \\
TOTAL & 320 & & \\
\hline
\end{tabular}


As a tool for data collection we opted for the application of questionnaires intercultural training for teachers in primary education [32]. These are two instruments, one aimed at the study of initial training, and the other to lifelong learning, designed in a Likert Scale format with four response options and structured into six categories of analysis (Table 4). The online form of the questionnaire was developed by using Google Forms application.

Table 4. Structure of intercultural training questionnaires for primary education teachers.

\begin{tabular}{ccc}
\hline & Questionnaire 1 & Questionnaire 2 \\
\hline Analysis Categories & Items & Items \\
\hline Sociodemographic Data & 4 & 8 \\
Theoretical-Practical, Contextualized and Flexible Training & 5 & 5 \\
Reflexive and Dialogical Training & 4 & 4 \\
Transverse Training & 2 & 2 \\
Participatory, Collaborative and Community Training & 5 & 4 \\
Global Rating & 1 & 1 \\
& Total = 21 & Total = 24 \\
\hline
\end{tabular}

After application of the questionnaires, it was necessary to study the reliability by the Cronbach alpha model, obtaining coefficients indicating high reliability: 0.853 and 0.889 in the questionnaire initial training and the submitted questionnaire about ongoing formation. Likewise, in the reliability analysis performed by each of the analysis categories, high coefficients were obtained (Table 5).

Table 5. Reliability analysis by categories: Alpha coefficient of Cronbach.

\begin{tabular}{ccc}
\hline & \multicolumn{2}{c}{ Cronbach's Alpha } \\
\hline & Questionnaire 1 & Questionnaire 2 \\
\hline Theoretical-practical, Contextualized and Flexible Training & 0.784 & 0.829 \\
Reflexive and Dialogical Training & 0.797 & 0.892 \\
Transverse Training & 0.831 & 0.813 \\
Participatory, Collaborative and Community Training & 0.712 & 0.808 \\
\hline
\end{tabular}

The information collected is completely anonymized in order to avoid disclosure of personal, confidential or sensitive data.

\section{Results}

Below are the results obtained by Sentan regarding processes initial and ongoing training.

\subsection{Study 1: Initial Teacher Training in Intercultural Education}

The results indicate that the training programs are addressed to current issues that influence the social and educational context. Most of the participants stated that reflection and debate about them are encouraged. More concretely, $54.4 \%$ declared to be quite in agreement with this affirmation and $26.3 \%$ declared total agreement with it. However, in relation to the promotion of learning of different cultures/languages and to the flexibility and adaptation of teaching, the degree of agreement of the participants is lower than in the aforementioned item. In fact, less than half said that learning different languages and cultures is promoted (30\% manifested to be quite in accord with the statement, and $19.4 \%$ expressed complete agreement), and more than half considered that the planning is not adapted to respond to the interests and needs of the students $(11.6 \%$ said they disagreed with the item, and $42.2 \%$ disagreed). 
Regarding the theoretical and practical nature of the training, the participants stated that the theoretical learning about interculturality and the work with students of foreign origin that provide practical examples are promoted to a greater extent. $65.7 \%$ stated that theoretical learning is promoted, while only $49.1 \%$ shows promotion for practical learning.

In relation to the processes of reflection on the multicultural school reality, the participants stated that both individual and group reflections are encouraged. More specifically, $76.9 \%$ stated that individual reflection is promoted, while $80.3 \%$ stated that group reflection is promoted.

On the other hand, the results indicate that the dialogical dimension is not promoted to a large extent. Slightly less than half said that it does not favor contact with people of different cultures $(47.8 \%)$, and just over half of them stated that it does not favor exchanges and debates on intercultural education among students of different degrees (58.4\%), nor contacts and relationships with people and/or social entities working for interculturality (53.5\%).

Likewise, from the results it follows that the acquisition of intercultural competences obtained by students is not necessarily planned and expresses itself transversely across the curriculum. More than $95 \%$ of the participants stated that the acquisition of intercultural competences is promoted only by certain subjects.

Regarding the promotion of collaborative work, although a high percentage of participants stated that work is promoted in collaborative groups $(89.7 \%)$, the percentage that said that the collaboration with different actors in the educational community $(27.6 \%)$ is encouraged was scarcer.

Regarding the community dimension, the participants state that the acquisition of strategies to work with families and the community in favor of interculturality is not favored. More specifically, half considered that strategies are not provided to work with families of students of foreign origin; and $76.3 \%$ considered that strategies to work with the community on topics related to immigration and interculturality are not provided.

Finally, in relation to the general evaluation of the training, the answers are divided. Slightly less than half considered that it does not provide sufficient intercultural skills to work in multicultural contexts, more specifically $43.4 \%$. This is a considerable and worrisome percentage, from which it can be deduced that there are deficiencies in the intercultural training of teachers (Tables 6 and 7). 
Table 6. Results on Initial Training in interculturality, by categories.

\begin{tabular}{|c|c|c|c|c|c|c|c|}
\hline & & $\begin{array}{l}\text { Completely } \\
\text { Disagree }\end{array}$ & $\begin{array}{l}\text { Slightly } \\
\text { Agree }\end{array}$ & $\begin{array}{l}\text { Mostly } \\
\text { Agree }\end{array}$ & $\begin{array}{l}\text { Completely } \\
\text { Agree }\end{array}$ & Average & $\begin{array}{l}\text { Standard } \\
\text { Deviation }\end{array}$ \\
\hline \multirow{5}{*}{$\begin{array}{l}\text { Theoretical-practical, } \\
\text { contextualized and } \\
\text { flexible training }\end{array}$} & $\begin{array}{l}\text { Encourages reflection and debate on current issues (social, cultural, } \\
\text { political, ethical, scientific, technological, etc.). }\end{array}$ & $2.8 \%$ & $16.6 \%$ & $54.4 \%$ & $26.3 \%$ & 3.04 & 0.735 \\
\hline & Promotes the learning of different cultures and languages. & $8.4 \%$ & $42.2 \%$ & $30 \%$ & $19.4 \%$ & 2.60 & 0.893 \\
\hline & $\begin{array}{l}\text { Adapt your planning to respond to the interests and needs } \\
\text { presented by students. }\end{array}$ & $11.6 \%$ & $42.2 \%$ & $33.8 \%$ & $12.5 \%$ & 2.47 & 0.856 \\
\hline & $\begin{array}{l}\text { Promotes the acquisition of theoretical learning about } \\
\text { interculturality and work with students of foreign origin. }\end{array}$ & $4.7 \%$ & $29.7 \%$ & $51.3 \%$ & $14.4 \%$ & 2.75 & 0.754 \\
\hline & $\begin{array}{l}\text { Promotes the acquisition of practical learnings about } \\
\text { interculturality and work with students of foreign origin. }\end{array}$ & $5 \%$ & $45.9 \%$ & $27.5 \%$ & $21.6 \%$ & 2.66 & 0.871 \\
\hline \multirow{4}{*}{$\begin{array}{c}\text { Reflexive and } \\
\text { dialogical training }\end{array}$} & $\begin{array}{l}\text { Encourages processes of individual reflection on the multicultural } \\
\text { school reality. }\end{array}$ & $3.8 \%$ & $19.4 \%$ & $57.8 \%$ & $19.1 \%$ & 2.92 & 0.728 \\
\hline & $\begin{array}{c}\text { Fosters processes of group reflection on the multicultural school } \\
\text { reality. }\end{array}$ & $3.4 \%$ & $16.3 \%$ & $57.5 \%$ & $22.8 \%$ & 3 & 0.728 \\
\hline & Promotes contact with people of different cultures & $5.9 \%$ & $41.9 \%$ & $25 \%$ & $27.2 \%$ & 2.73 & 0.928 \\
\hline & $\begin{array}{c}\text { Encourages exchanges and debates on intercultural education } \\
\text { among students of different degrees. }\end{array}$ & $10.9 \%$ & $47.5 \%$ & $27.2 \%$ & $14.4 \%$ & 2.45 & 0.870 \\
\hline \multirow{2}{*}{$\begin{array}{l}\text { Transverse } \\
\text { training }\end{array}$} & Promotes the acquisition of intercultural skills in all subjects. & $29.1 \%$ & $59.7 \%$ & $11.3 \%$ & - & 1.82 & 0.610 \\
\hline & Integrates the intercultural perspective transversally in all subjects. & $40 \%$ & $48.4 \%$ & $6.9 \%$ & $4.7 \%$ & 1.76 & 0.776 \\
\hline \multirow{5}{*}{$\begin{array}{l}\text { Participatory, } \\
\text { collaborative and } \\
\text { community } \\
\text { training }\end{array}$} & $\begin{array}{l}\text { Encourages collaboration with different agents of the educational } \\
\text { community. }\end{array}$ & $10.3 \%$ & $62.2 \%$ & $21.3 \%$ & $6.3 \%$ & 2.23 & 0.716 \\
\hline & Promotes collaborative group work. & $2.5 \%$ & $7.8 \%$ & $38.8 \%$ & $50.9 \%$ & 3.38 & 0.737 \\
\hline & $\begin{array}{l}\text { Favors the acquisition of strategies to work with families of } \\
\text { students of foreign origin. }\end{array}$ & $18.1 \%$ & $31.9 \%$ & $40.3 \%$ & $9.7 \%$ & 2.42 & 0.895 \\
\hline & $\begin{array}{l}\text { Encourages the acquisition of strategies to work with the } \\
\text { community on topics related to immigration and interculturality. }\end{array}$ & $25 \%$ & $51.3 \%$ & $23.4 \%$ & $0.3 \%$ & 1.99 & 0.706 \\
\hline & $\begin{array}{l}\text { Facilitates contacts and relationships with people and/or social } \\
\text { organizations that work in favor of interculturality. }\end{array}$ & $6.9 \%$ & $46.6 \%$ & $30.9 \%$ & $15.6 \%$ & 2.55 & 0.836 \\
\hline Overall rating & $\begin{array}{c}\text { Provides sufficient and appropriate intercultural skills to work in } \\
\text { multicultural context. }\end{array}$ & $10.3 \%$ & $33.1 \%$ & $45.3 \%$ & $11.3 \%$ & 2.58 & $0.823 *$ \\
\hline
\end{tabular}

* Note: The standard deviations in all categories are low, indicating that there is little dispersion among the responses obtained in each item. 
Table 7. Summary data categories.

\begin{tabular}{cccc}
\hline & Average & Standard Dev & Rank \\
\hline Theoretical-practical, Contextualized and Flexible Training & 13.55 & 2.67 & $5-20$ \\
Reflexive and Dialogical Training & 11.10 & 2.57 & $4-16$ \\
Transverse Training & 3.58 & 1.29 & $2-8$ \\
Participatory, Collaborative and Community Training & 12.57 & 2.44 & $5-20$ \\
Overall Rating & 2.58 & 0.82 & $1-4$ \\
Total Score & 43.36 & 7.32 & $17-68$ \\
\hline
\end{tabular}

\subsection{Study 2: In-Service Teacher Training in Intercultural Education}

The results indicate that the training programs are addressed to current issues that influence the social and educational context. More than half of the participants stated that reflection and debate about them are encouraged. More specifically, $57.5 \%$ manifested to quite agree with the statement, and $10 \%$ fully agreed with the same. On the other hand, in relation to the promotion of the learning of different cultures/languages and to the adaptation of teaching, the degree of agreement is lower than in the aforementioned item. Barely 35\% stated that they promote the learning of different cultures and languages, and that they offered answers to the real needs and interests of teachers working in multicultural contexts.

As for the theoretical and practical training, participants stated that theoretical learning about multiculturalism is promoted, while work with differences coming from students of foreign origin or any substantial training in practical learning is less so. $73.8 \%$ stated that theoretical learning is promoted, while only $30 \%$ stated that practical learning is promoted. Comparing the results obtained in this category with the results in relation to the initial training, we observe that in regard to permanence, training in practical learning is promoted to a lesser extent.

Regarding the process of reflection on the multicultural school reality, more than half said that it fosters both individual and group reflection. More specifically, $60 \%$ stated that reflection and critical analysis is promoted on the practice itself in interculturality (50\% were quite in agreement with the item and $10 \%$ completely agree). Further, $66.3 \%$ stated that group reflection is promoted $(53.8 \%$ were quite in agreement with the item and $12.5 \%$ totally agree). At this point it is appreciated that both individual and group reflection processes are promoted to a greater extent from the initial training.

In relation to the dialogical dimension, $67.5 \%$ stated that contacts and relationships with people and/or social entities that work towards interculturality are facilitated ( $57.5 \%$ were quite in agreement with the item and 10\% totally agree). However, only 35\% stated that spaces are provided for communication with professors from other countries and cultural backgrounds ( $25 \%$ agreed with the item and $10 \%$ agree completely).

On the other hand, the results indicate that the intercultural perspective is not integrated transversally in all training actions. More than half said they disagreed with this item $(57.6 \%)$. Although this is a lower percentage than that obtained in relation to initial training, we consider that it is a warning percentage.

Regarding the promotion of collaborative work, we find that, even though more than half said that collaborative work groups is promoted $(63.8 \%)$, collaboration with different agents of the educational community is encouraged to a lesser degree (43.1\%, according to the item). When comparing these results with those of the initial formation we observed that, while the work in collaborative groups is promoted to a greater extent in the initial formation processes, the collaborative work with different agents of the educational community is promoted to a greater extent in the processes of permanent formation.

As for the community dimension, the acquisition of strategies for working with families of students of foreign origin is favored ( $87.6 \%$ mostly or strongly agreed with the item). However, only $32.5 \%$ said that the community is involved in the development of training activities. Comparing the results with those obtained in relation to the initial training we detected that, although the acquisition of strategies 
from permanent formation to work with the families of the students of foreign origin is promoted to a greater extent, the work with the rest of the educational community continues to be a challenge for training programs, both initial and permanent.

Finally, as regards the general assessment of lifelong learning in the field of interculturality, we observe that the answers were again divided. Approximately $60 \%$ considered that it does not offer answers to the real needs of teachers working in multicultural contexts and does not provide sufficient intercultural skills to work in multicultural contexts. As in the case of initial training, this is a worrying percentage that points to deficiencies in intercultural teacher training (Tables 8 and 9).

Finally, a multivariate analysis was carried out to assess the influence of sex and the university of reference in the perception of the students in relation to the intercultural training offered by the Degree in Primary Education, including as dependent variables all the factors and the total score of the questionnaire. The MANOVA inferential analysis led to the conclusion that there were statistically significant differences due to gender $(p=0.020, F(5000)=2.734$, Lambda de Wilks $=0.957 ; \eta 2=0.043)$, although it is significant that the size of the effect is low according to eta square, which may point to the fact that the differences are too low to take them into account. In addition, in the tests of inter-subject effects, no significant differences were found in any of the factors in a univariate way according to sex. On the other hand, depending on the university of origin, the differences were not statistically significant $(p=0.845, \mathrm{~F}(35,000)<1$, Wilks' lambda $=0.917 ; \eta 2=0.017)$. Neither were they statistically significant in the sexual interaction according to the university of origin $(p=0.991, \mathrm{~F}(30,000)<1$, Wilks' lambda $=0.953 ; \eta 2=0.010$ ).

On the other hand, a multivariate analysis was carried out to assess the influence of sex and age the teachers' perception in relation to lifelong learning in intercultural matters, including as dependent variables all the factors and the total score of the questionnaire. The MANOVA inferential analysis led to the conclusion that there were statistically significant differences due to gender $(p=0.000$, $F(5000)=16.797$, Wilks' lambda $=0.455 ; \eta 2=0.545)$. However, in testing between-subject effects, only significant differences in one of the form factors were found univariate by gender, in this case, in the reflective and dialogical training $(p=0.004 ; \eta 2=0.104)$, and that if we look at its effect size, it does not show an important difference either. On the other hand, depending on age, differences were also statistically significant $(p=0.000, \mathrm{~F}(10,000)=18.615$, Wilks' lambda $=0.184 ; \eta 2=0.571)$. In this case, in the tests of inter-subject effects, significant differences were found in all the factors due to age (Theoretical-practical, contextualized and flexible training $p=0.000 ; \eta 2=0.202$; reflexive and dialogical training $p=0.032 ; \eta 2=0.089$; transversal training $p=0.000 ; \eta 2=0.227$; overall assessment $p=0.000$; $\eta 2=0.336$; and total score $p=0.001 ; \eta 2=0.179$; for all factors mentioned here, older people had a higher mean, which means better training of inter-subject effects) except factor $\mathrm{f}$ (participatory formation and collaborative community $(p=0.326 ; \eta 2=0.030))$ where there were no differences. Differences in sex and age interaction were also found $[p=0.000, \mathrm{~F}(10,000)=18.588$, Wilks' lambda $=0.185 ; \eta 2=0.570]$. 
Table 8. Results on permanent formation in the field of interculturality, by categories.

\begin{tabular}{|c|c|c|c|c|c|c|c|}
\hline & & $\begin{array}{l}\text { Completely } \\
\text { Disagree }\end{array}$ & $\begin{array}{l}\text { Slightly } \\
\text { Agree }\end{array}$ & $\begin{array}{l}\text { Mostly } \\
\text { Agree }\end{array}$ & $\begin{array}{l}\text { Completely } \\
\text { Agree }\end{array}$ & Average & $\begin{array}{l}\text { Standard } \\
\text { Deviation }\end{array}$ \\
\hline \multirow{5}{*}{$\begin{array}{l}\text { Theoretical-practical, } \\
\text { contextualized and } \\
\text { flexible training }\end{array}$} & $\begin{array}{l}\text { Promotes reflection and debate on current issues (social, cultural, } \\
\text { political, ethical, scientific, technological, etc.). }\end{array}$ & $7.5 \%$ & $25 \%$ & $57.5 \%$ & $10 \%$ & 2.7 & 0.735 \\
\hline & $\begin{array}{l}\text { Offers answers to the real needs and interests of teachers working } \\
\text { in multicultural contexts. }\end{array}$ & $26.3 \%$ & $38.8 \%$ & $25 \%$ & $10 \%$ & 2.19 & 0.943 \\
\hline & Promotes the learning of different cultures and languages. & $17.5 \%$ & $47.5 \%$ & $25 \%$ & $10 \%$ & 2.28 & 0.871 \\
\hline & $\begin{array}{l}\text { Promotes the acquisition of theoretical learning about } \\
\text { interculturality and work with students of foreign origin. }\end{array}$ & $3.8 \%$ & $21.3 \%$ & $42.5 \%$ & $32.5 \%$ & 3.04 & 0.834 \\
\hline & $\begin{array}{l}\text { Promotes the acquisition of practical learnings about } \\
\text { interculturality and work with students of foreign origin. }\end{array}$ & $26.3 \%$ & $38.8 \%$ & $25 \%$ & $10 \%$ & 2.19 & 0.943 \\
\hline \multirow{4}{*}{$\begin{array}{l}\text { Reflexive } \\
\text { and dialogical } \\
\text { training }\end{array}$} & $\begin{array}{l}\text { Promotes reflection and critical analysis on the practice itself in } \\
\text { interculturality. }\end{array}$ & $7.5 \%$ & $32.5 \%$ & $50 \%$ & $10 \%$ & 2.63 & 0.769 \\
\hline & $\begin{array}{l}\begin{array}{l}\text { Fosters processes of group reflection on the multicultural school } \\
\text { reality. }\end{array}\end{array}$ & $7.5 \%$ & $26.3 \%$ & $53.8 \%$ & $12.5 \%$ & 2.71 & 0.783 \\
\hline & $\begin{array}{l}\text { Facilitates spaces for communication with professors from other } \\
\text { countries and cultural backgrounds. }\end{array}$ & $33.8 \%$ & $31.3 \%$ & $25 \%$ & $10 \%$ & 2.11 & 0.994 \\
\hline & $\begin{array}{l}\text { Facilitates contacts and relationships with people and/or social } \\
\text { organizations that work in favor of interculturality. }\end{array}$ & $7.5 \%$ & $25 \%$ & $57.5 \%$ & $10 \%$ & 2.70 & 0.753 \\
\hline \multirow{2}{*}{$\begin{array}{l}\text { Transverse } \\
\text { training }\end{array}$} & $\begin{array}{c}\text { Integrates the intercultural perspective transversally in all training } \\
\text { actions. }\end{array}$ & $8.8 \%$ & $48.8 \%$ & $32.5 \%$ & $10 \%$ & 2.44 & 0.793 \\
\hline & $\begin{array}{l}\begin{array}{l}\text { Favors the acquisition of intercultural competences in all training } \\
\text { actions. }\end{array}\end{array}$ & $27.5 \%$ & $30 \%$ & $20 \%$ & $22.5 \%$ & 2.38 & 1.118 \\
\hline \multirow{4}{*}{$\begin{array}{l}\text { Participatory, } \\
\text { collaborative and } \\
\text { community } \\
\text { training }\end{array}$} & $\begin{array}{l}\text { Encourages collaboration with different agents of the educational } \\
\text { community. }\end{array}$ & $11.3 \%$ & $47.5 \%$ & $27.5 \%$ & $13.8 \%$ & 2.44 & 0.869 \\
\hline & Promotes collaborative group work. & $5 \%$ & $31.3 \%$ & $45 \%$ & $18.8 \%$ & 2.78 & 0.811 \\
\hline & $\begin{array}{l}\text { It favors the acquisition of strategies to work with families of } \\
\text { students of foreign origin. }\end{array}$ & $3.8 \%$ & $8.8 \%$ & $38.8 \%$ & $48.8 \%$ & 3.33 & 0.792 \\
\hline & Involves the community in the development of training actions. & $8.8 \%$ & $58.8 \%$ & $23.8 \%$ & $8.8 \%$ & 2.33 & 0.759 \\
\hline Overall rating & $\begin{array}{l}\text { Provides sufficient and appropriate intercultural skills to work in } \\
\text { multicultural contexts. }\end{array}$ & $17.5 \%$ & $40 \%$ & $32.5 \%$ & $10 \%$ & 2.35 & $0.887^{*}$ \\
\hline
\end{tabular}

${ }^{*}$ Note: The standard deviations in all categories are low, indicating that there is little dispersion among the responses obtained in each item. 
Table 9. Summary data categories.

\begin{tabular}{cccc}
\hline & Average & Standard Dev & Rank \\
\hline Theoretical-practical, Contextualized and Flexible Training & 12.38 & 3.35 & $5-20$ \\
Reflexive and Dialogical Training & 10.15 & 2.88 & $4-16$ \\
Transverse Training & 4.81 & 1.77 & $2-8$ \\
Participatory, Collaborative and Community Training & 10.86 & 1.67 & $4-16$ \\
Overall Rating & 2.35 & 0.88 & $1-4$ \\
Total Score & 40.56 & 8.44 & $16-64$ \\
\hline
\end{tabular}

\section{Discussion and Conclusions}

Based on the results obtained, we can conclude that the initial and in-service teacher training programs present certain characteristics that favor intercultural education:

They use processes of individual and group reflection on the multicultural school reality [24], and promote work in collaborative groups. However, it should be noted that collaboration is promoted to a greater extent among the participants of the training processes themselves. In this sense, we consider it essential to stimulate and extend interuniversity collaboration, as well as collaboration with third sector entities and active participation in cooperative experiences carried out in the community. Teachers are trained in interculturality when they live in their center with teachers from other cultures, participate in ambitious programs of Euro-teaching staff, or intercontinental networks, and discover the multilocality, while sharing the problems, desires, and concerns of many different social groups [33].

On the contrary, the results also suggest that training programs have certain characteristics that hinder the promotion of intercultural training:

Decontextualization and inflexibility. In spite of the legal framework [34], the aim is to adapt the teaching to new training needs, offer contextualized training, and make training strategies more flexible. We detect that these aspects still pose a challenge for the teacher training system [23].

Primacy of the theoretical learning over the practical ones, especially in the case of permanent formation. If we underestimate the importance of theoretical knowledge, we consider it essential to demonstrate the practical application of it. Also, it is necessary to enhance the experiential character of the formative processes and link them to reality, so as to favor meaningful learning.

Limited promotion of knowledge about different cultures and languages. It is essential to acquire basic knowledge about different cultures and languages, since ignorance can lead to educational approaches and proposals based on erroneous stereotypes and prejudices.

Non-transverse character does not cross the cultural training [25]. We understand that training to address cultural diversity should be developed transversally across all disciplines with the aim of reinforcing the commitment to the inclusion of cultural diversity as a key axis of the learning process to teach [3]. Likewise, we consider that promoting intercultural competences must not be done only from modules, subjects and/or specific subjects aimed at attention to cultural diversity, that is, not only from abstractions; despite the virtues that this type of training entails, in a certain sense the foundations of the intercultural education model are contradictory, since, from a deficit vision of the difference, specific subjects are incorporated to face a "concrete problem" (education specific for specific groups, educational compensation, etc.). It is a formation that incorporates this principle: The different students in cultural terms are students with special educational needs, understood in the classical sense of the term 'special education' [35].

Limited dialogue. Given that dialogue is one of the main components of multiculturalism, we consider it necessary that training processes create dialogue among all students, teachers and other agents, which are part of the educational community; in this way, communication is strengthened.

Non-community character. All intercultural training process must be based on the principles of respect and intercultural communication among all authorities of the educational community. In the World Declaration on Higher Education of UNESCO [36] it was indicated that higher education requires a renewal of the contents, methods, practices and means of transmission of knowledge, which 
must be based on new types of links and collaboration with the community, and a deep structural transformation. Collaboration with the community is thus one of the main educational methods in higher education although it is not promoted enough through teacher training [26].

All this points to the idea that intercultural training continues to be a challenge for the initial and in-service teacher training system in Andalusia. This idea is reaffirmed by the students themselves, and teachers, since a considerable percentage shows that the training processes do not provide enough intercultural skills to work in multicultural contexts.

The current study presents some limitations, mainly due to method. Quantitative methodology has limitations in its capacity to provide a comprehensive understanding of the topic. As future research developments, we propose to development qualitative studies to understand teacher perceptions more in depth. Furthermore, we are committed to studying ways to modify the characteristics of current training programs that hinder the promotion of intercultural teacher training.

Author Contributions: Conceptualization, V.F.-C. and M.C.L.B.; methodology, C.S.R.; software, L.O.J.; validation, L.O.J., and C.S.R.; formal analysis, C.S.R.; investigation, V.F.-C. and M.C.L.B.; resources, V.F.-C.; data curation, C.S.R.; writing - original draft preparation, V.F.-C. and M.C.L.B.; writing-review and editing, L.O.J. and C.S.R.; visualization, C.S.R.; supervision, C.S.R.; project administration, L.O.J. All authors have read and agreed to the published version of the manuscript.

Funding: This research received no external funding.

Acknowledgments: This work has been developed with funding from the Center for Studies on Migration and Intercultural Relations (CEMRI) of the University of Almeria and the research POCTEFEX_ANDALUCÍA INTEGRA (0051_ANDALUCIA_INTEGA_2E), belonging to the European Regional Development Fund (ERDF).

Conflicts of Interest: The authors declare no conflict of interest.

\section{References}

1. Fernández, J.M.; Aguilar, J.M. Competencias docentes interculturales del profesorado de Educación Física en Andalucía (España). Movimento 2016, 2, 753-766.

2. Aneas, A.; Luna, E.; Palou, B. Integración curricular del desarrollo de competencias interculturales en la Universidad. In Desarrollo de Competencias Interculturales en Contextos Universitarios; Salmerón, H., Rodríguez, S., Cardona, M.L., Eds.; Patronat Sud-Nord Solidaritat i Cultura de la Fundació General de la Universitat de Valencia i Publicaciones de la Universitat de Valencia: Valencia, Spain, 2012; pp. 121-145.

3. Hinojosa, E.F.; López, M.C. La relevancia de las creencias sobre diversidad cultural en la formación del docente. In II Congrès Internacional de Didàctiques; Universitat de Girona: Girona, Spain, 2010.

4. Folgueiras, P.; Martínez, M. El desarrollo de competencias en la universidad a través del Aprendizaje y Servicio Solidario. Rev. Interam. Educ. Para Democr. 2009, 2, 56-76.

5. Walters, A.; Vilches, M.L. Integrating teacher learning: The schoolbased follow-up development activity. ELT J. 2000, 54, 126. [CrossRef]

6. Aguado, M.T. El enfoque intercultural como metáfora de la diversidad en educación. In Educación Intercultural: Perspectivas y Propuestas; Aguado, M.T., Del Olmo, M., Eds.; Centro de Estudios Ramón Areces: Madrid, Spain, 2010; pp. 13-27.

7. Sales, A.; Traver, J.A.; García, R. Action research as a school-based strategy in intercultural professional development for teachers. Teach. Teach. Educ. 2011, 27, 911-919. [CrossRef]

8. Essomba, M.A. Liderar Escuelas Interculturales e Inclusivas. Equipos Directivos y Profesorado Ante la Diversidad Cultural y la Inmigración; GRAÓ: Barcelona, Spain, 2006.

9. Brodin, J.; Lindstrand, P. Perspective of a school for all. Int. J. Incl. Educ. 2007, 11, 133-145. [CrossRef]

10. Lloyd, C. Removing barriers to achievement: A strategy for inclusion or exclusion? Int. J. Incl. Educ. 2008, 12, 221-236. [CrossRef]

11. Sleeter, C.E. Pedagogies of inclusion in teacher education. In Beyond Pedagogies of Exclusion in Diverse Childhood Contexts; Mitakidou, S., Tressou, E., Swadener, B.B., Grant, C.A., Eds.; Palgrave Macmillan: New York, NY, USA, 2009; pp. 149-166. 
12. García, J.L. La formación permanente del profesorado: Motivaciones, realizaciones y necesidades. Educ. XXI Rev. Fac. Educ. 1998, 1, 129-158.

13. Escarbajal, A. La formación del profesorado en comunicación intercultural. In I Congreso Internacional Virtual de Formación del Profesorado; Universidad de Murcia: Murcia, Spain, 2010.

14. Sales, A. La formación intercultural del profesorado: Estrategias para un proceso de investigación-acción. Educ. Siglo XXI 2012, 30, 113-132.

15. Leiva, J.J. La formación en educación intercultural del profesorado y la comunidad educativa. In Revista Electrónica de Investigación y Docencia (REID); Número Monográfico Octubre: Jaen, Spain, 2012; pp. 8-31.

16. López, E.; Pérez, E. Formación permanente del profesorado y práctica docente intercultural: Contenidos actitudinales y complementariedad competencial. Espiral. Cuad. Profr. 2013, 6, 32-42. [CrossRef]

17. García, L.; Arroyo, M.J. La formación del profesorado en Educación Intercultural: Un repaso sobre su formación inicial y permanente. Rev. Nac. Int. Educ. Inclusiva 2014, 7, 127-142.

18. He, Y.; Lundgren, K.; Pynes, P. Impact of short-term study abroad program: Inservice teachers' development of intercultural competence and pedagogical beliefs. Teach. Teach. Educ. 2017, 66, 147-157. [CrossRef]

19. Pence, H.M.; Macgillivray, I.K. The impact of an international field experience on preservice teachers. Teach. Teach. Educ. Int. J. Res. Stud. 2008, 24, 14-25. [CrossRef]

20. Biraimah, K.L.; Jotia, A.L. The longitudinal effects of study abroad programs on teachers' content knowledge and perspectives: Fulbright-Hays group projects abroad in Botswana and Southeast Asia. J. Stud. Int. Educ. 2013, 17, 433-454. [CrossRef]

21. Gómez, I.M.; Medina, A.; Gil, P. La competencia intercultural en el plan de estudios de Graduado en Maestro de Educación Infantil en la Universidad de Castilla La Mancha. ENSAYOS 2011, 26, 35-54.

22. Peñalva, A.; López-Goñi, J.J. Competencias ciudadanas en alumnado de magisterio: La competencia intercultural personal. Rev. Electrónica Interuniv. Form. Profr. 2014, 17, 139-153. [CrossRef]

23. Aguado, M.T.; Mata, P. Impulsar la formación continua del profesorado en centros y redes. In Libro Blanco de Educación Intercultural; FETE-UGT, Ed.; Secretaría para la Igualdad de la Comisión Ejecutiva Confederal de UGT y Secretaría de Políticas Sociales de la Federación de Trabajadores de la Enseñanza: Madrid, Spain, 2010; pp. 45-46.

24. Biasutti, M.; Concina, E.; Frate, S. Social sustainability and professional development: Assessing a training course on inetercultural education for in-service teacher. Sustainability 2019, 11, 1238. [CrossRef]

25. Cernadas, F.X.; Santos, M.A.; Lorenzo, M.M. Los profesores ante la educación intercultural: El desafío de la formación sobre el terreno. Rev. Investig. Educ. 2013, 31, 555-570. [CrossRef]

26. Escarbajal, A.; Morales, A. Estudio de las competencias interculturales del profesorado en Educación Secundaria. IJERI 2016, 6, 146-161.

27. Cernadas, F.X.; Lorenzo, M.M.; Santos, M.A. Diversidad cultural y escenarios migratorios. Un studio sobre formación de profesores. Educar 2019, 55, 19-37. [CrossRef]

28. Civitillo, S.; Juang, L.P.; Schachner, M.K. Challenging beliefs about cultural diversity in education: A synthesis and critical review of trainings with pre-service teachers. Educ. Res. Rev. 2018, 24, 67-83. [CrossRef]

29. Wereszczyńska, K. Importance of and need for intercultural education according to students: Future teachers. Pol. J. Educ. Stud. 2018, 1, 212-228. [CrossRef]

30. Tomé, M.; Herrera, L.; Lozano, S. Teachers' Opinions on the Use of Personal Learning Environments for Intercultural Competence. Sustainability 2019, 11, 4475. [CrossRef]

31. Ruiz, J.I. Metodología de la Investigación Cualitativa; Universidad de Deusto: Bilbao, Spain, 2003.

32. Figueredo, V.; Ortiz, L. Construcción y validación de cuestionarios de formación intercultural para el profesorado de Educación Primaria. InterSciencePlace 2017, 12, 146-160. [CrossRef]

33. Medina, A.; Domínguez, C. Formación del profesorado: Aprendizaje profesional en contextos interculturales. XXI Rev. Educ. 1999, 1, 69-97.

34. Consejeria de Educación Junta de Andalucia. Decreto 93/2013, de 27 de agosto, por el que se regula la formación inicial y permanente del profesorado en la Comunidad Autónoma de Andalucía así como el Sistema Andaluz de Formación Permanente del Profesorado; Boletín Oficial de la Junta de Andalucía: Seville, Spain, 2013; pp. 6-50. 
35. Carrasco, M.J.; Coronel, J.M. Percepciones del profesorado sobre la gestión de la diversidad cultural: Un estudio cualitativo. Educ. XX1 2017, 20,75-98. [CrossRef]

36. UNESCO. La Educación Superior en el Siglo XXI. In Visión y Acción; UNESCO: Paris, France, 1998.

(c)

(C) 2020 by the authors. Licensee MDPI, Basel, Switzerland. This article is an open access article distributed under the terms and conditions of the Creative Commons Attribution (CC BY) license (http://creativecommons.org/licenses/by/4.0/). 